\title{
Harnessing Gadaa System as a Black Covenant in Modern Constitutional Administration: Appraisal of Prospects and Challenges
}

\author{
Solomon Emiru Gutema \\ Wollega University, Nekemte, Oromia, Ethiopia
}

Copyright $(2017$ by authors, all rights reserved. Authors agree that this article remains permanently open access under the terms of the Creative Commons Attribution License 4.0 International License

\begin{abstract}
Gadaa system is a well comprehensively guided, crafted and nurtured system of traditional administration under the unbelievable wisdom of the ancient Oromo people in the horn of Africa. It is difficult to recall exactly when and where Gadaa system had started. However, it is determined beyond any reasonable doubt that the Oromo people have been utilizing Gadaa system as a traditional mechanism to ensure social justice for centuries. It is possible to consider Gadaa system as an unwritten form of the nation's covenant or constitution in modern sense. It is developed and evolved from the cumulative experiences gained from experiments, practices, customs, and lessons of many generations of the Oromo society in a very long period. Accordingly, Gadaa system is extremely broad and comprises of all aspects life like religion, Politics and culture of the Oromo people. Nevertheless, this paper puts its emphasis on exploring the prevailing prospects and challenges in harnessing Gadaa system as constitutional administration in modern democratic governance. Hence, to achieve its goal, the researcher employs qualitative method which includes reviewing the existing and relevant literatures, assessing legal documents like FDRE Constitution of 1995, and evaluating the Gadaa tradition in comparison with the modern principles of Constitutional administration. Therefore, the findings of this research claim that Gadaa system is a covenant for the Oromo people. Since all Oromo, in all age groups will give their consent to select or elect their representatives/leaders. Since the people puts limitations on the powers of elected representatives through the principles of Gadaa administration and furthermore, as the nation have Gadaa system as guarantees to make their leaders accountable and transparent both legally and politically in their day to day official decisions. For this reason, the researcher recommended that all the concerned party in general and all the Oromo scholars and peoples in particular must strive a lot in harnessing the principles of Gadaa system in their modern administration at national and international level.
\end{abstract}

Keywords Gadaa System, Oromo, Administration

\section{Introduction}

In any government system of the world, the current system of governance has its roots in the traditional system of administrations. According to political history, certain countries have been molding their customary laws to the stage of current developed constitutional governance. For instance, England has been evolving her customary or common laws at the level of the most legitimate unwritten Constitution in the world in modern time. Therefore, it is her common or unwritten constitution and laws which made up the strength of England in history (De Salviac, 1901) [1]. Hence, to be democratic it is not absolutely necessary to have codified systems of governance; whether written or unwritten, the subject matters and the legitimacy of principles of governance matters to have genuine and constitutional administration system. In the same scenario, the Oromo peoples have been utilizing the unwritten Gadaa principles to ensure its legitimate and democratic traditional system of governance. Accordingly, we should not have trouble concerning the unwritten principles of the Gadaa system of the Oromo. Therefore, the Oromo people who hadn't known how to write and read had had a Gadaa system as unwritten Constitution.

Here in this paper the researcher argues that it is better to build the current constitutional and democratic administrations in coupled with the legitimate traditional principles of administrations like Gadaa system of the Oromo. It is not appropriate to take hasty generalization that all traditional system of administrations is acceptable; since there may be various problems in using traditions in modern administrations. Sometimes, the traditions may be accompanied by harmful traditional practices, as well as, it may affects the modern concepts of human rights, constitutionalism, rule of law and the right to equality.

However, Gadaa system is the well-crafted and nurtured traditional system of governance which protects the human rights, ensures democratic governance, rule of law and constitutionalism. Far before the invention of all these concepts of human rights and democratic administrations and earlier than their incorporation in the well-known 
Human Rights Declarations and Covenants like UDHR, CCPR, CESCR, CRC, and others in human history, Gadaa system recognizes, enforces, and fulfills all these concepts of human rights and constitutionalism. For instance, in $16^{\text {th }}$ century, when human beings were hunted, made slave and sold like property, the Oromo people had been committed to the protection of human rights (Makoo Bilii Laws, Article 13, 41, 55) [2]. According to various evidences Makoo Bilii laws which is parts of the Gadaa system of the Maccaa Oromo was enacted in 1580s (Dirribi, 2011) [3]. This law protects, females, children, refugees, and ensures equal protection and equal subjection of laws, adoption, accountability and transparency of the highest authorities (Ibid) [3]. Moreover, Gadaa system has been governing all the aspects of Oromo system of governance in the most democratic manner. It deals the government branches separately as in law making, in adjudication and law enforcements like the modern democratic Constitutions.

Generally, in the history of states formations, constitutions have enacted in different manners and for various purposes. Consequently, some constitutions are imposed by the rulers for suppressing the subjects/citizens without the interest and participation of the ruled. In this governance system, the model of state formation and political organization is hierarchical (Daniel, Volume 3) [4] like states formed through conquest, dictatorship, and Monarchical government.

On the other hand, some states were evolved organically out of more limited forms of human organization and which over time concretize power centers which govern their peripheries (Ibid) [4]. Polities founded and organized on the organic model seemingly grow naturally, and as they develop, the more powerful or otherwise talented leaders form a political elite at the polity's center that rule over the vast majority in the polity, who are relegated to the peripheries (Ibid) [4].The constitutions of the organically created states are enacted through evolution from the traditional body of accepted rules and customary practices (Ibid) [4]. The apotheosis of this model is Westminster-style parliamentarianism with the parliament sovereign (Ibid) [4].

Furthermore, some states are founded by design through covenant or compute in which power is shared through a matrix of centers formed by the government of the whole, on the basis of federal principles (Ibid) [5]. The covenantal model is different from the above ways of state formation. Since, under the covenantal model of polities formation, at least two states, one is the federal state and the other is the regional states must bargain between themselves on all political, social and economic aspects of the nation's living in that polity (George, 2008)[5]. This covenantal model of state formation is all about federation or federal way of organizing a polity in certain country. Hence, federations are originated from particular bargains on various issues related to political and socio-economic aspects of the public at large, which struck at a particular time and designed to serve for generations (Assefa, 2000)[6]. In these bargaining between the federal and sub-units on a number of issues, a written and supreme constitution necessitates mandatorily (Ibid) [6].

Based on these three political theory of polities formation, the Oromo Gadaa system shares the characteristics of the second (Organic Model) and mainly the third (Covenantal Model); since it shares the characteristics of both models. Similarly in Gadaa system of the Oromo each clan or pair of clans of Oromo possessed religious and political centres (Odaa) where assemblies take place for religious or political purposes. However, even though each clan possess Odaa of their own, all of them have blessing of the 'Abba Mudaa' (Ritual and cultural leader) at one centre altogether. Accordingly, there was one Abba Mudaa at one centre at a time to bless all the Oromo clans rules in different regions who were autonomously administer themselves with the binding general Gadaa system. Hence, the Oromo have had Abba Mudaa which unifies them and they have been administering themselves autonomously in other aspects. Thus, the researcher strongly claims that there are the concepts of shared rules and self-rule in Gadaa system like in the modern covenantal Constitutions of federations.

Therefore, the researcher strongly argued that it is possible to mould the Gadaa system into covenantal model of modern constitution to strengthen and have a viable federal system of government in multi-diversified countries like Ethiopia. In so doing, we Africans can formidably come up with a unique democratic model of state formation in parallel with these western democracies. That is the reason why the researcher prefers Gadaa system as a black covenant in modern constitutional administration.

\section{Material and Methods}

This research has attempted to make an appropriate review of the existing literature on Gadaa system, Constitutionalism, rule of laws and broadly on concepts of constitutional administration. It explores the ways in which one can utilizes the principles of Gadaa system as a modern covenantal based constitution. Moreover, it endeavors to scrutinize the prospects and challenges encountering in molding Gadaa system in the form of covenantal model of modern constitutional administration.

Additionally, it strives to explore legal and practical opportunities prevailing in Ethiopia and at global level to utilize the principles of Gadaa system in civilized world. To fulfill these objectives, it reviews various literatures written on Gadaa system, constitutional governance, federalism, and traditional administration. Furthermore, critically it analysis the principles of democratic governance recognized under the FDRE Constitution of 1995, as well as, other relevant laws including national laws and international treaties in comparison with the principles in Gadaa system of governance.

For this reason, its research methodology is qualitative one. Hence, various related literatures, FDRE Constitution, other relevant laws, international covenants ratified by Ethiopia and the practices in Ethiopia and elsewhere will be analyzed and compared in detail in order to show the 
prevailing possible challenges and constitutional options for warranting Gadaa system as a black covenant in Africa and elsewhere in the world.

\section{Result and Discussions}

\subsection{Gadaa System as Covenantal Constitution}

As elaborated hereinabove, in a federation written and Supreme Constitution is considered as the covenant among the peoples or ethnic groups living in that particular federalist state on one hand and between the citizens and the government on the other hand. Accordingly "Every covenant involves consenting, promising and agreeing" (Daniel, Volume 3) [7]; and the same scenario is workable for the federal constitution, since it is considered among the nations, nationalities and peoples of certain federal country like Ethiopia.

Consequently, the peoples living in federation give their consents on their political, social, economical, cultural and historical aspects in detail manners as much as possible for them by directly or indirectly involved through their legitimate representatives (FDRE Constitution, Preamble, USA Constitution etc) [8]. As a result, after giving consents and bargaining on all affairs mainly on the fate of their political and socio-economic affairs, they put promises or guarantees for the violations of their agreement under the fundamental constitution (Ibid, Preamble and Article 39 i.e. the right to self-determination up to secession) [8].

Apparently the rationale behind in bargaining in all their political, social, economic, cultural and other affairs by multi-diversified societies in the form of covenant under their supreme constitution in federation is to ensure everlasting peace and thereby to realize sustainable development. Hence, unless the various ethnic groups are empowered to participate and determine on the fate of their political and socio-economic affairs; it is hardly possible to ensure sustainable development and everlasting peace especially in federation.

In the same approach, the Gadaa system consists of all the core concepts of covenantal based Constitution. The critical investigation of the Gadaa system reveals that it fulfills the three main elements (consenting, promising and agreeing) of a covenantal Constitution of modern democratic federation like USA, Germany, India, Ethiopia and others. Because, as all the Oromo give their consent to enact, to implement and to enforce Gadaa principles and exercising the practices of self-administration for thousands of years. They (each clan) have agreed to administer themselves autonomously and also agreed to have some common center and rules that govern the affairs of all the Oromo's at once like 'Abbaa Mudaa'. Gadaa system is an elaborate, well-constructed system for distributing power among all the generational segments of society (Asmerom, 2006) [9]. The law of Gadaa of the Oromo cannot be break or collapse by any means after it has made; which means, "Tumeen Seera! Hinjigu, hin dhangala'u; seera Gadaa Oromooti" (Dirribi, 2011) [10]. Additionally, the Oromo has a genuine custom of transferring authority (Baallii) timely. In Oromo seizing power in it longer than the time it is expected to be transferred is abnormal (unconstitutional) (Ibid) [10]. It is believed that if one doesn't transfer authority (Baallii) he may phase as a punishment from God (Ibid) [10]. Hence, the Oromo have their Gadaa system as a guarantee or promise for administering themselves through shared rule and self-rule very similar with the modern covenantal/ federal system of administration without any suspicions about the violation of their private and collective rights.

\subsection{The Failure to Accommodate Gadaa Principles in Modern Covenantal Constitution}

African countries have been striving a lot to shape their state formation and governmental structures in the way of western democracies in the postcolonial eras. Most of the African countries have been striving to have similar political paradigms and state structures like the western states to ensure democracy and constitutionalism. Accordingly, People have looked for solutions and paradigms everywhere, including state building based on Western concepts of democracy; nevertheless, "changes" in the desired directions remain elusive (Asmarom, 2006) [11].

To guarantee democratic and constitutional governance, which flourished in western countries like France, Great Britain, USA; African states have employed a number of techniques. Legal transplantation has taken place at different time and in different places. Legal transplantation refers to the transfer of legal rules, legal principles and legal concepts from one or more than one legal system to another legal system. For instance, the concepts of rule of law, accountability and transparency of government officials, supremacy of the constitution, sovereignty of the people, sanctity of human rights and other related principles of constitutional administration systems are entirely transplanted or imported from the western democracies after they have nurtured there for centuries.

Despite of this massive legal transplantation, it remains a puzzle for social scientists those who have been grappling with the question of why post-colonial Africa has failed to achieve any semblance of democracy, peace, stability and development (Asmarom, 2006) [11]. Hence, though African countries have imported different principles of democracy like constitutional administration, rule of law, various human rights principles, principles of constitutionalism, still yet African people and states are suffering from undemocratic governance. Consequently, border conflicts, state instability, civil war, poverty, rampant corruption are remain the brand of African governments now days.

Thus, it is rational to quest why all these political and socio-economic hardships are remaining immutable to the majority of African governments' regardless of the reception of these democratic principles of governance and state structure from the westerners. For instance, Ethiopia has 
been tackling for centuries to improve her government structure and legal system to modernize the people and the system of administration. Since, Tewodros the second and even before, the kings of Abyssinia and later after unification of the country under Menelik the second; system of administration and governance have been imported in to Ethiopia. As an illustration, Ethiopia transplanted the concepts of 1931 Constitution from the Japan constitutional system. Additionally, the 1955 Revised Constitution of Ethiopia was directly copy pasted from the Westminster style of England. Furthermore, the 1987 Ethiopian Constitution was sociality oriented one, and its contents derived substantially from the former USSR (Soviet Union) Constitution. Moreover, the 1995 current Federal Democratic Republic of Ethiopian Constitution and the constitutional and democratic principles embodied in its contents are also taken from foreign federal oriented constitutions like USA Constitution and the Basic Law of Germany. The well known internationally recognized human rights and democratic governance principles are accommodated in the contents of FDRE Constitution of 1995.

From these above illustrations, one can understand that Ethiopia enacted four types of Constitutions in the last century. However, these Constitutions are not related to one another. That means, the prior constitution cannot be used as stepping stone for the newer constitution. Hence, in making the new constitution, the old constitution is not as such important or one cannot use the old one as stepping stone to make the new Constitution. For instance, the 1931 of Ethiopian Constitution was derived from the Japan Constitution. Whereas, the 1955 Revised Constitution of Ethiopia was from England. Therefore, when we analyze this, the people of Japan and people of Ethiopia are completely different. Their culture, religion, type (diversity), geography and history, are not similar. Japan has composed of a people of same race/ethnic, almost same religion and culture; accordingly, they developed their monarchical 'Meji' Constitution. However, Ethiopia is composed of multi-diversified society, different religions, traditions, and history.

Likewise, England accommodated her laws and legal system since 'Magna Carta' of 1215 . Hence, her laws and Constitution have been evolving for more than eight hundred years starting from conception of 'Magna Carta'. For this reason, it is too difficult to enact Constitution based on this very complex and unwritten system of governances and constitutional model for Ethiopia. However, the then monarchical government failed to accommodate the Gadaa system, rather they were eager to import such evolved laws from England. The same thing is workable in the case of 1987 Ethiopian Derg Constitution. It received its ideology from the socialist legal system which has nothing relation with the Ethiopian people. Surprisingly, neither the 1995 FDRE Constitution nor the 2001 Regional State Constitution of Oromia has incorporated the principles of Gadaa system it is contents.

\subsection{Harnessing Gadaa Principles in Modern Constitutional Administration (Prospects)}

There are numerous principles of Gadaa system which are compatible with the modern constitutional and democratic administration. Hence, the researcher would like to categorize and analyze all the available prospects to utilize Gadaa system in modern constitutional administration hereunder in the following appraisals:

In modern form of constitutional and democratic governance; a written document which is named as Constitution is both legal and political document; which governs the legal, political and socio-economic aspects of certain nation. Constitution contains principles, objectives, values and guideless on a very important national matters and interests like political, social and economic objectives. Moreover, it gives directions on country's foreign policy, election system, language policy, religion policy, matters of human and democratic rights, and system of governments, fiscal matters and others. Generally, Constitution serves as a framework for government organs, limits the power of governments, ensure rule of law and democracy, guaranty rights and freedoms for citizens, forging unity among diversities, develops human dignity and values which calls for sustainable development. The Gadaa system is also fulfills all these functions of modern Constitution of the democratic states.

Hereunder, the researcher briefly examines and evaluates the well-known principles of constitutional government; and thereby attempts a lot to point out the consistency of Gadaa principles with modern Constitutions' of these democratic republics. Accordingly, the researcher would like to compare the modern democratic governances' principles like Sovereignty of the people, Supremacy of the Constitution, Sanctity of Human Rights, Accountability and transparency government officials, Separation of powers, and Rule of Law

\section{a) The Principles of Sovereignty of the People}

The sovereignty of the people means, all the sovereign power vests in the hand of the people and their sovereign power is expressed in the Constitution (FDRE Constitution, Article 8(1, 2)) [12]. Their sovereignty shall be expressed through their representatives elected in accordance with this Constitution and through their direct democratic participation (Ibid, Article 8(3)) [12]. The sovereign power here is all about the power of deciding on all internal economic, political, social, cultural, legal and other matters which have paramount importance to them jointly and individually. This means there can be no authority that can stop people from making what they believe in. The sovereignty of the people principles embodied abroad spectrum of rights; such as, the right to self-determination, which includes, the right to autonomy regarding to language, history, culture, self-rule, and representation (UDHR, ICCPR, ICESCR) and FDRE Constitution, Article 8,39)[12]. 
This sovereign power is exercised directly by the nation, nationality and peoples or indirectly by their representatives pursuant to Article 8 (3) of the constitution.

In the same scenario, the Oromo Gadaa system consists of smart principles which guarantee the principle of sovereignty of the people. The Oromo believe or have had a premise which claims that the law stands above all men. But the law does not above its makers or legislative assemble which represent the Oromo people in making laws. That is the reason why the statement that says, "The Oromo are governed by the law made by the people" goes right true is (Dirribi, 2011) [13]. According to Asmarom:

"One of the most interesting aspects of Oromo tradition is that laws are treated as a product of human deliberation not a gift of God or of heroic ancestors. There is little in Oromo thought that suggests that laws are natural and, therefore, immutable. There is even less evidence that suggests that the laws are supernatural and, therefore, beyond discussion. On the contrary, they say that all their laws were created by men and can thus be change by men" (Asmarom, 2006)[13] .

Therefore, all these elaboration here above embraces that even though law stands above all people; the makers are the peoples and they use the law as an instrument to fulfill the public interest to ensure peace and security and thereby warrant sustainable development. Hence, the makers (legislative assembly) or the representatives of the people at large are sovereign to make and unmake the laws on behalf the people.

Again Dirribi has written the following which precisely point out the sovereignty of the people:

In Oromo democratic culture, the supreme power is not in the hands of those well-respected individuals (elders) having the knowledge of law making. It is also not in the hands of electoral committees, the 'Ayyaantuus', who get power through inheritance. The ultimate power holder is again not in the hand of 'Abba Duulaa' who gives military leadership for the armies; or those who are in the stage of kuusaa (qondaalaa) and gives military service in an organized way. All these have nothing to do with the ultimate power. The Abba Gadaa who is administering the country have no such authority. However, the supreme authority belongs to the people's Gumii (Assembly) the representatives of the people." (Dirribi, 2011)[14]

Thus, the sovereign power is vests in the hand of the people and the people are also considered as sovereign in the Gadaa system of the Oromo similar with modern constitution.

\section{b) Supremacy of the Constitution}

The supremacy principle shows that the decisions of the nations, nationalities and peoples which are expressed and embodied in the constitution are immutable and cannot be violated by any force, law or body. No actions of bodies of representative democracy (the legislature, the executive, the judiciary and their officials) may override the decisions of the whole people as emblazoned in the constitution.

According to Supremacy principle, the Constitution is the supreme law of the land; any law, customary practice or a decision of an organ of state or a public official which contravenes this Constitution shall be of no effect (FDRE Constitution, Article 9)[15]. All citizens, organs of state, political organizations, other associations as well as their officials have the duty to ensure observance of the Constitution and to obey it (Ibid) [15].

The Supremacy principle in Gadaa system is more genuine than the modern Constitution in guaranteeing the supremacy of Constitution/ Core Gadaa Principles. The premise that laws stand above all men is the foundation of Oromo's Gadaa administration laws (Dirribi, 2011) [16]. The Oromo are accustomed to govern by the law made by the people (Ibid) [16]. Concerning this Professor Asmarom has witnessed the following:

"The Abba Gadaa himself is subjected to the same punishment as all other Borana if he violates laws, same laws, and same punishments. That is the evidence that shows us that law is above everybody including the Abba Gadaa."(Asmarom, 2006)[17]

These all point out that the Oromo have recognized and enforced the supremacy of basic laws/principles similar with the now days Constitution without any hesitation.

\section{c) The Principle of Sanctity of Human Rights}

According to the modern democratic Constitution, Human rights and freedoms, emanating from the nature of mankind are inviolable and inalienable (FDRE Constitution, Article 10, UDHR, ICCPR, and ICESCR) [18]. Human rights and fundamental freedoms are therefore, not given by the state or authorities but pre-exist their legal recognition by the state or the authorities. Because of the universal nature of human beings, Human rights are endowed with certain universal rights which are natural, inalienable and inviolable.

Consequently, these human rights includes the right to life, prohibition against inhuman treatment, freedom of movement, the right to free from torture, the right to food, shelter and clothing, the right to equality, the right to have health and clean environment, and others (FDRE Constitution, Chapter Three, UDHR, ICCPR, ICESCR) [19]

Though majority of the traditions and traditional and customary practices are incompatible with the modern principles of human rights; But, majority of the Gadaa principles are consistent with the principles of sanctity of human rights. That is the reason why 'Neo-liberal Approach or Democratic Pragmatism theorists' refused to accept traditional form of governance in modern civilized world.

The opponents of the school of organic democracy (Neo-liberal Approach or Democratic Pragmatism theorists) firmly argue against the proponents of indigenous governance; claiming that it is inherently defective and they cast doubts as to their compatibility with democratic values and fundamental human rights principles (Ntsebeza and Luugisile, 2005) [20]. Despite the arguments, Gadaa system 
extends its human rights protection to animals and natural worlds not only human beings. Therefore, even Gadaa principles respects, fulfills and enforces human rights principles even far better than the modern constitutions and international human rights covenants. The following illustrations best justifies these arguments as follows:

Among the Oromo people, not only human rights, but the rights of dogs are legally respected. That is why the Borana people say, "Seerri muummee seera saree" and the Tulama also say "Huuru dheeroo akka seeri, huuru gabaabo akka seeri" They mean dog and cat. Having a dog is not compulsory but if you have it, feeding is necessary (Dirribi, 2011) [21]. Professor Asmarom also argues that:

Galma Liban said that the law does not only disciple the highest, it also protects the lowest. By way of illustration, he suggested that the dog is one of the lowest creatures in Borana: nevertheless, there are laws that protect him from harm. Borana says that "Seerri muummee seer-saree" (Asmarom, 2006) [22]

Furthermore, Balambaras Jabessa Ejjeta (who was born in 1909 in Horroo-Guduruu) had written the following human rights protection in the Oromo:

"The Oromo considered the an already born child as human being; all human beings have humanitarian dignity; A child of a nation is just like one's own; and the problem of the wife is the problem of the husband, any cattle has dignity."(Dirribi, 2011)[23].

Therefore, it is possible to conclude that the Oromo people have created and utilizing Gadaa system; which respects and exercises human rights for both mankind and animals at all. Thus, it is possible to claim that Gadaa respects and enforces the principles of sanctity of human rights like the modern written and codified constitution of the western democracies.

d) Accountability and Transparency of Government Officials

Pursuant to the modern constitutional government, the conduct of affairs of government shall be transparent; as well as, any public official or an elected representative is accountable for any failure in official duties (FDRE Constitution, Article 12) [24]. In case of loss of confidence, the people may recall an elected representative (Ibid)[24]. This principle makes the political appointees, elected people like House of Peoples' Representatives, and top appointed public servants transparent and accountable.

This accountability of public officials is both political and legal responsibility. Transparency for instance has to be measured against clear standards and requirements to be placed in detailed legislations and similarly accountability may be ensured by putting in place clear duties and responsibilities of the appointed and elected officials in various laws that pertain to their areas of operation, and by penal legislation in case of violations (Getachew Assefa, 2012) [25].

Both the elected and appointed government officials cannot escape from responsibility under democratic leadership. This responsibility is both legal and political. If the representatives of the people didn't fulfill their duty in favor of the people or the constituency who elected them, they will punish them with their cards up on election, so the right to elect is one guarantee to ensure development. So the right to elect is the best instrument the unproductive representatives from their seat. In addition to this, any government officials are subjected to legal punishment and court trial according to the law if they commit crime.

Accordingly, Gadaa system consists of principles of transparency and accountability in an excellent manner. The major principles in Gadaa Laws is not only protecting the rights of the weak, but also controlling and limiting the highest authorities (Dirribi, 2011)[26]. According to the law of accountability of Gadaa system, any authority that goes beyond his legitimate power shall be accused. Hence, the feudal oriented tradition that says, "Samay ayitaresim Nigus ayikasasim" which means, "As it is impossible to plough the sky, the king cannot also be accused" has no place in Oromo Gadaa system. Moreover, the concepts of special privilege for the government officials are not recognized in Oromo Gadaa system.

In Oromo, all are answerable to the laws. Even though Abba Gadaa cannot be assassinated but he can be removed from his office if he abuses his power according to Borana Oromo. Hence, after dismissed from power, now he can be punished just like other individuals; therefore, the only privilege of Abba Gadaa is that he is immune against capital punishment (Ibid) [26]. Under Gadaa system, the General Assembly serves this purpose (assessing the performance of leaders' in the first-half of the term office); it may endorse the presidents' continuation or uproot a leader before completion of his term (Zelalem, 2015) [27]. Unlike the presidents and premiers across sub-Saharan African countries, where they stay on power for unlimited period of time, the single term office principle under the Gadaa leadership reveals an incredible value of democracy (Ibid) [28].

Even today, most of the Constitutions of states do not put the term office of the top executive like Prime Ministers and Presidents. For instance, the 1995 FDRE Constitution of Ethiopia does not specify how many times can be a certain Prime Minister re-elected is not precisely specified whilst in Gadaa system no one can be re-elected as Abba Gadaa for the second time under any condition.

\section{e) The Principle of Separation of powers}

In the modern democratic constitution, especially in federation power may be separated horizontally between the federal and regional states. This is vertical division of power between the federal and states in a federation of power are named as division of power. Whereas, the division or sharing of power among the three wings of governments (Legislature, Executive and Judiciary) is considered as separation of power. The main behind the principles is to protect the people against capricious tyrannical and whimsical powers of the State (Tej Bahadur, 1999) [28]. 
Accordingly The FDRE Constitution also shares the power among three wings of government both at federal and regional level. The Federal Democratic Republic of Ethiopia comprises the Federal Government and the State members (FDRE Constitution, Article 50(1)) [29]. The Federal Government and the States shall have legislative, executive and judicial powers (Ibid, Article 50(2[29].

The Gadaa system also recognizes the principles of separation of powers. The Gadaa is entitled with powers to govern country and defend it from the enemy (Dirribi, 2011) [30]. For instance, the Kuusaa (qondaalaa) has the rights and responsibilities of attacking the enemy up on request (Ibid) [30]. The Gumii (Assembly) has the powers of changing laws, advising and guiding the Gadaa or uprooting and making other elections (Ibid) [30]. The Ayyaantuus (Abba Mudaa) also has the powers to decide Election Day, to bless the authorities like the ya'aas, jiila, Gumii, and Abba Gadaas (Ibid) [30]. All groups work in cooperation and they do not have the superiority and inferiority complexities (Ibid) [30].

However, unlike the division of powers between the federal and the states, the Gadaa System of division of power follows generation and age-group based power division (Zelalem, 2015) [31]. It is the type of division of power in which every citizen involves actively in political and legal affairs of their country (Ibid) [31]. Hence, the Gadaa ensures the separation and divisions of powers even far better than the modern democratic constitutions. Since, the division of power is across the generation, so it has great value in creating egalitarian society. It is all inclusive political system in which all age group shoulder responsibilities.

\section{f) The Principle of Rule of Law}

The expression 'rule of law' has been derived from the French phrase 'la principle de legalite', meaning a government based on the principles of law. Rule of law indicates the state of affairs in a country in main the law rules. If rule of law is prevailing in certain country there is no rule of men.

Accordingly, rule of law propagates the principle of supremacy of law on one hand and the equality of all (equality before the law, or the equal subjection of all classes to the ordinary law of the land administered by the ordinary law courts). In addition to this according to the modern concepts the principles of rule of law may also implies that the functions of government in a free society should be exercised so as to create conditions in which the dignity of man, as an individual, is upheld (Delhi Declaration, 1959 and Logos Declaration 2967[32] .

However, the perception of rule of law among the Borana is a bit different. According to one of my informants, rule of law signifies not only liability of individuals rather it also means that everything and all beings have rules (Zelalem, 2015) [33] "That is the law stands not only for the benefit of individuals or to discipline officials but it also extends to animals. In this respect, the Borana say that seerri muummee, seera saree! Literally it may mean as, "a law for a minister is a law for a dog” (Ibid) [33]. Asmarom also claimed that that the Borana states that there are laws for everything, even for the dog (Asmarom, 2006) [34].

To sum up this section, the Gadaa system of the Oromo accommodates and recognizes the principles similar to the modern democratic Constitutions of various republics. Sometimes, it guarantees human rights almost like the modern legitimate Constitution as appropriately explained hereinabove.

\subsection{Challenges in Harnessing Gadaa Principles in Modern Constitutional Administration}

Despite of the available opportunities analyzed hereinabove discussions; there are a number of barriers in utilizing Gadaa system in modern Constitution. The researcher would like to categorize these challenges as theoretical, Historical, and Legal. Each of these concepts is analyzed as follows:

\section{a) Theoretical Challenges}

Theoretically, the concepts of Indigenous Knowledge in general and indigenous governance like Gadaa system in particular can be classified in two. Accordingly, there are two contradicting theories concerning harnessing the traditional system of governance like Gadaa system in modern democratic administration.

The School of Organic Democracy (Neo-Traditionalist Position) believes that traditional leadership like Gadaa system has the capacity to build democracy from below (Sithole, Pearl and Thamsanqa Mbele, 2008)[35]. This theory accepts and recognizes the traditional system of governances like Gadaa system is compatible at least at principle level with modern democratic governance (Ibid) [35].

However, Neo-liberal Approach or Democratic Pragmatism School seriously opposes the traditional governance system like Gadaa system. They strongly argue that indigenous governance system like Gadaa principles is inherently defective and they cast doubt as to their compatibility with democratic values and fundamental human rights principles (Ntsebeza and Luugisile, 2005) [36].

These theorists (neo-liberalists) supporter prioritize individual rights rather than group rights. Additionally, the claim that the principles of democracy demand state nations that ensures access to democracy as a commodity to which all humans are entitled (Christensen Karen and David Levinson, 2003) [37]. They argue that in the era of globalization and economic integration it is unthinkable to utilize the traditional system of governance like Gadaa system (Ibid) [37]. They contest the traditional system of governance as decentralized and time taking, hence, it is labor and time intensive, since all the people gathered and discuss on different issues. Therefore, collecting all the people and empowering them in decision making in the deliberative or consensual democracy model's practicality is next to impossible (ECA, Economic Commission for Africa, 2007) [38]. Thus, these Neo-liberalists position of averting the traditional system of governance like Gadaa system in 
the era of modern globalization and economic integration is one among different challenges in harnessing Gadaa system in modern Constitutional administration.

\section{b) Historical Challenges}

It is clearly known that the history of the Oromo people in general and Gadaa system in particular was written not by the Oromo themselves in the earliest time. The Habesha, Europeans and the Arabs were writing the history of the Oromo (Dirribi, 2011) [39]. Therefore, the majority of these alien writers were reflected their hatred and tried to despise the Oromo history and culture (Ibid) [39].

The Habesha writers (historians) like Abba Bahire had had strived a lot to harm the psychology of the Oromo people and thereby destroyed culture and religion. He said the Oromo people are cruel and inhuman in his book entitled as history of the Oromo. Moreover, Professor Mesfin Woldemariyam says, "The Oromo military force has no other objective than destroying" (Mesfin, 1972) [40]. Furthermore, Professor Getachew Haile argues that the Oromo people were ignorant and destroyed the Habesha's civiliazation by invading civilized Habesha people (Getachew Haile, 2002[41] The European writers have affected and blurred the history of the Oromo system, particularly the Gadaa system though some the European writers like Martial De Salviac, Antoine D'Abbadie and others have strived a lot to write the true history of the Oromo people.

For instance, the Portuguese who like the Habesha, and hate the Oromo people in the past; as they did not know the Oromo or Oromo language at that time. However, they got distorted information and facts about the Oromo from the Habesha people only (Dirribi, 2011) [42]. Moreover, even though the Arabs came to Africa for trade and religion purpose, they wrote the history of the Oromo in negative manner like some of the Europeans as they employed the sources they got from the Habesha monarchies and priests without crosschecking it.

Moreover, historically the Oromo people have resisted the colonizers for centuries and protecting themselves and their land. However, since $19^{\text {th }}$ century, they have been crushed by their enemies (Ibid) [42]. After captured by the enemies through war, their history and culture have been violated and seriously destroyed (Ibid) [42].

As a result, continuously the history of the Oromo people were disturbed and cracked for centuries. Consequently, the Oromo have been suffering symbolic and cultural segregations within the Ethiopian Empire. For instance, Professor Mohammed Hassen argued as follows same manner as follows:

"The new Ethiopian ruling class, typified by Emperor Menelik... found it necessary and profitable to denigrate the Oromo people, their culture, and their history in all ways great and small. This ruling class especially perceived the danger of the larger Oromo population to its empire. Consequently, the ruling class systematically depicted the
Oromo as people without history, and belittled their way of life, and their religious and political institutions (Mohammed, 1990) [43]. Thus, history affects the development of Gadaa system negatively, and also, it has an immense effect on current status of Gadaa system.

\section{c) Legal Challenges}

In history of Ethiopia until the flourishing of federalism in Ethiopia in 1991, Gadaa system is prohibited or banned by the laws at different time. Starting from Menelik II (1889) up to the introduction of federal democratic state structure which was established under the 1995 FDRE Constitution, Gadaa system was banned by the Government laws. Hence, utilizing and promoting Gadaa system was unthinkable during Monarchies and during the Military regime (Derg) in Ethiopia.

Even today under the federal system of Ethiopia, it is too difficult to promote and harness Gadaa principles in molding and enacting Regional State Constitution and Federal Constitution. Since both the 1995 FDRE Constitution and the Oromia Regional State Revised Constitution of 2001 have not accommodated the principles of Gadaa system at all. Of course, the 1995 FDRE Constitution incorporates Articles which give home for utilizing the traditional governance system. For instance, Article 34(5) says, "This Constitution shall not preclude the adjudication of disputes relating to personal and family laws in accordance with religious or customary laws, with the consent of the parties to the dispute. Particulars shall be determined by law." Furthermore, the same Constitution says, "Every Nation, Nationality and People in Ethiopia has the right to speak, to write and to develop its own language; to express, to develop and to promote its culture; and to preserve its history." as per its, Article 39 (2)). Moreover, it claims that government shall have the duty to support, on the basis of equality, the growth and enrichment of cultures and traditions that are compatible with fundamental rights, human dignity, democratic norms and ideals, and the provisions Constitution (FDRE Constitution, Article 91(1)).

Additionally, at the regional level of Oromia Gadaa system only recognized as a traditional ritual ceremony only. The 2001 regional state Constitution of Oromia and its amendments are not give consideration to Gadaa principles. This regional Constitution is the direct replica of the federal Constitution (FDRE Constitution of 1995) [44]. Also, this regional Constitution is subordinate to the federal Constitution (FDRE Constitution, Article 9) [44]. Accordingly, the regional state Constitution of Oromia is molded inline of the FDRE Constitution. Hence, this is a serious legal challenge as the Gadaa principles are not recognized at least at regional state level of Oromia.

\section{d) Failure to Accommodate Gadaa Principles in Educational Policy/Curriculum}

The Educational policy or Curriculum of Ethiopia does not accommodate satisfactorily the principles of Gadaa 
system neither at federal level nor at regional level of Oromia in its curriculums both at primary and higher education level. A critical investigation of the Ethiopian educational curriculum pointed out that the Principles of Gadaa system is rarely highlighted or touched in courses like History and Civics only.

Rather than accommodating these Golden principles, the educational courses contain the history of Ethiopian monarchies like Tewodros, Yohannes, Menelik, Hailesellasie and others. There is no center which promotes, gives training and conduct researches about Gadaa system in detail. Hence, this may be considered as a serious challenge, since without educating the generation, and conducting further studies about Gadaa system a comprehensive and detailed manner; it is very difficult to mold these Gadaa principles in modern Constitutional governance.

\section{Conclusions}

Gadaa system is a very complex and deeply interwoven system which governs all the affairs of the whole Oromos. It directs the political, socio-economic and religious aspects of the Oromo peoples since the time immemorial. Even though when and where Gadaa system was originated is not precisely known; it is determined beyond any reasonable doubt that Gadaa system was originated and nurtured by and among the Oromo peoples for centuries.

Verily, Gadaa system of the Oromo consists of is the best traditional system of democratic governances in itself. Consequently, these golden principles of the Gadaa system had been employed during 16th century when human beings were hunted like wild animals for slavery. It accommodates the principles of human rights, Child rights, Sovereignty of the people, accountability of governors, separation of power, rule of law, separation of power and others far before the recognitions of these concepts in the western countries like France, England, USA and others.

However, the genuine and comprehensive system has not been succeeded to be a part of modern Constitutional documents or contents. Even though it contains well known principles of modern constitutional governance, like the now days constitutional documents; Gadaa principles do not accommodated both under the Federal and Regional state Constitutions in the federalist state of Ethiopia. Despite of its compatibility, the reasons why the drafters of Constitutions both at Federal and Regional State of Oromia failed to accommodate the principles of Gadaa system in the contents of their Constitutional laws respectively is remained anomaly.

Moreover, there are amble prospects to have and to mold Gadaa system as the modern black Constitution for African states in general and for Ethiopia both at regional and federal levels in the future. Since, Gadaa system can be utilized as a source from where any government can fetch the Golden principles of democratic governance and culture of tolerance in multi-diversified countries like Ethiopia and other African
Countries. Thus, it is astonishing to tackle with transplanting foreign legal system in to Africa rather than molding and harnessing the principles of Gadaa system which the Oromos have been utilizing for more than 500 years.

To sum up, Gadaa system can be used as a stepping stone to guarantee and ensures the principles of modern constitutional administration in modern governance system especially at regional level Oromia, as well as, at federal level in Ethiopia. Therefore, Gadaa system can be considered as a black covenant for the black peoples (Africa) as the same as that of the white covenant of that USA Federal Constitutional democracy.

\section{Recommendation}

The researcher would like give the following recommendations for all interested parties as the following:

In history there is not time when Gadaa system have got recognition by the Ethiopian rulers. Sadly; the federalist state of Ethiopia is also reluctant to give recognition for this blessed system of governance. In addition to insult to injury, in their self-administration system at regional level, the Oromia state representative (leaders) did not accommodate the principles of Gadaa system in their government branches (Legislative, Executive and Judiciary).

Accordingly, the researcher warns the Chafe Oromia to incorporate the principles of Gadaa system in the contents of Regional Constitution. Additionally, the governments both at federal and regional level must avert the wrongly written history on Gadaa system of the Oromo in their day to day actions and inactions. The center for Gadaa studies and research on how to harness Gadaa system in modern governance must be established. The Gadaa system must be incorporated in the School curriculum both at primary and higher institution levels.

Moreover, as the principles of Gadaa system is available in oral form (Unwritten), the Government of Oromia, the Oromo elites, researchers, students and others concerned bodies must strive a lot to collect all these principles in documented (written) form. Furthermore, Abba Gadas must teach the generations through training, media, and any other available mechanisms to empower the young generations.

Again, the weak parts of Gadaa principles must be identified and corrected in the way of modern democratic governance principles and international human rights covenants. Additionally, symbols which represent the Gadaa system in general, must be planted in big cities like Finfinne.

Finally, the researcher would like to recommend all the Oromos and friends of Oromos to implement heartily the well-known songs of Doctor Artist Ali Birra in order to harness Gadaa system as a black covenant in the modern Constitutional administration system: This Oromo version of Dr. Ali Birra says:

$$
\begin{gathered}
\text { "Where is the way to Abba Gadaa's Hall? } \\
\text { Let me enhance its hall } \\
\text { Let me sit down and write its history." }
\end{gathered}
$$




\section{REFERENCES}

[1] Father Martial De Selviac, An Ancient People in the State of Menelil, The Oromo, Great African Nation, Paris, 1901

[2] Makoo Bilii Laws, 1580s, (It is a customary law which was enacted/ declared orally by the Great Oromo Law Maker named as Makoo Bilii (the leaders of the Oromo) in 1580s.

[3] Dirribi Demissie Bokku (2011), Oromo Wisdom in Black Civilization, Finfine Printing \& Publishing S.C., April 2011, Ethiopia.

[4] Elazar Daniel J. (1998), Covenant and Constitutionalism: The Great Frontier and the Matrix of Federal Democracy Introduction - The Covenant Tradition in Politics, Volume 3

[5] Anderson George (2008), Federalism An Introduction, Published in Canada by Oxford University Press.

[6] Assefa Fisseha (2006), Federalism and Accommodation of Diversity in Ethiopia: A comparative Study (Wolf Legal Publisher, Nijmegen, and the Netherlands).

[7] Elazar Daniel J. (1998), Covenant and Constitutionalism: The Great Frontier and the Matrix of Federal Democracy Introduction - The Covenant Tradition in Politics, Volume 3

[8] FDRE, Constitution of the Federal Democratic Republic of Ethiopia, (Proclamation No. 1/1995, Negarit Gazetta, Addis Ababa, 1995).

[9] Asmarom Legesse (2006), Oromo Democracy, An Indigenous African Political System, Trenton, NJ: Red Sea Press.

[10] Dirribi Demissie Bokku (2011), Oromo Wisdom in Black Civilization, Finfine Printing \& Publishing S.C., April 2011, Ethiopia.

[11] Asmarom Legesse (2006), Oromo Democracy, An Indigenous African Political System, Trenton, NJ: Red Sea Press.

[12] FDRE, Constitution of the Federal Democratic Republic of Ethiopia, (Proclamation No. 1/1995, Negarit Gazetta, Addis Ababa, 1995) and UDHR, ICCPR, ICESCR

[13] Asmarom Legesse (2006), Oromo Democracy, An Indigenous African Political System, Trenton, NJ: Red Sea Press.

[14] Dirribi Demissie Bokku (2011), Oromo Wisdom in Black Civilization, Finfine Printing \& Publishing S.C., April 2011, Ethiopia.

[15] FDRE, Constitution of the Federal Democratic Republic of Ethiopia, (Proclamation No. 1/1995, Negarit Gazetta, Addis Ababa, 1995).

[16] Dirribi Demissie Bokku (2011), Oromo Wisdom in Black Civilization, Finfine Printing \& Publishing S.C., April 2011, Ethiopia.

[17] Asmarom Legesse (2006), Oromo Democracy, An Indigenous African Political System, Trenton, NJ: Red Sea Press.

[18] FDRE Constitution, Article 10, UDHR, ICCPR, and ICESCR.

[19] (FDRE Constitution, Chapter Three, UDHR, ICCPR, ICESCR).
[20] Ntsebeza, Luugisile, Democracy Compromised: Chiefs and the Politics of the Land in South Africa.(Leiden and Boston: Brill, 2005).

[21] Dirribi Demissie Bokku (2011), Oromo Wisdom in Black Civilization, Finfine Printing \& Publishing S.C., April 2011, Ethiopia.

[22] Asmarom Legesse (2006), Oromo Democracy, An Indigenous African Political System, Trenton, NJ: Red Sea Press.

[23] Dirribi Demissie Bokku (2011), Oromo Wisdom in Black Civilization, Finfine Printing \& Publishing S.C., April 2011, Ethiopia.

[24] FDRE, Constitution of the Federal Democratic Republic of Ethiopia, (Proclamation No. 1/1995, Negarit Gazetta, Addis Ababa, 1995), Article 12.

[25] Getachew Assefa, (2012), Ethiopian Constitutional Law, with comparative notes and materials, a text book, School of Law, Addis Ababa University, published by American Bar Association, 321 North Clark Street, Chicago, Illinois, USA.

[26] Dirribi Demissie Bokku (2011), Oromo Wisdom in Black Civilization, Finfine Printing \& Publishing S.C., April 2011, Ethiopia.

[27] Zelalem Tesfaye, 2015), Old Wine in new bottles: Bridging the peripheral, Gada rule to the Mainstream Constitutional order of the 21st c. Ethiopia, Oromia Law Journal [Vol.4, No.1].

[28] Tej Bahadur Singh (March 1999), Principle of Separation of Powers and Concentration of Authority, Published Institute's Journal.

[29] FDRE, Constitution of the Federal Democratic Republic of Ethiopia, (Proclamation No. 1/1995, Negarit Gazetta, Addis Ababa, 1995), Article 50(1).

[30] Dirribi Demissie Bokku (2011), Oromo Wisdom in Black Civilization, Finfine Printing \& Publishing S.C., April 2011, Ethiopia.

[31] Zelalem Tesfaye, 2015), Old Wine in new bottles: Bridging the peripheral, Gada rule to the Mainstream Constitutional order of the 21st c. Ethiopia, Oromia Law Journal [Vol.4, No.1].

[32] International Commission of Jurists, known as Delhi Declarations, in 1959, which was later on confirmed at Logos in 1967.

[33] Zelalem Tesfaye, 2015), Old Wine in new bottles: Bridging the peripheral, Gada rule to the Mainstream Constitutional order of the 21st c. Ethiopia, Oromia Law Journal [Vol.4, No.1].

[34] Asmarom Legesse (2006), Oromo Democracy, An Indigenous African Political System, Trenton, NJ: Red Sea Press.

[35] Sithole, Pearl and Thamsanqa Mbele (2008), Fifteen years Review on Traditional Leadership, (A Research Paper, Human Science Research Council).

[36] Ntsebeza and Luugisile(2005), Democracy Compromised: Chiefs and the Politics of the Land in South Africa.(Leiden and Boston: Brill).

[37] Christensen Karen and David Levinson, 2003(eds.), Encyclopedia of Community: From the Village to the Virtual World, Vol 1, (A-D, Sage Publications. 
[38] ECA, (Economic Commission for Africa) (2007), Relevance of African Traditional Institutions of Governance, (Economic Commission for Africa, Publications and Conference Management Section (PCMS), Addis Ababa, Ethiopia).

[39] Dirribi Demissie Bokku (2011), Oromo Wisdom in Black Civilization, Finfine Printing \& Publishing S.C., April 2011, Ethiopia.

[40] Mesfin Woldemariyam (1972), An Introductory Geograph of Ethiopia, Addis Ababa.

[41] Professor Getachew Haile (2002), Ye Abba Bahire Dirsetoch
Oromowoch Kememeleketu Leloche Senedoch Gara (Addis Ababa).

[42] Dirribi Demissie Bokku (2011), Oromo Wisdom in Black Civilization, Finfine Printing \& Publishing S.C., April 2011, Ethiopia.

[43] Mohammed Hassen (1990), The Oromo of Ethiopia: A History 1570-1860 Cambridge University Press.

[44] FDRE, Constitution of the Federal Democratic Republic of Ethiopia, (Proclamation No. 1/1995, Negarit Gazetta, Addis Ababa, 1995), Article 50. 